\title{
THE HISTORICAL FIGURE OF OMAR AL- MUKHTAR AND ISLAMIC MARTYRDOM IN INDONESIA
}

\author{
Frank Dhont
}

Yale University, USA

\begin{abstract}
The story of Omar al-Mukhtar resisting Italian colonisation of Libya had great potential as a rallying point for anti-colonial sentiment in the Indies stirred up by Islamic politicians under a Pan-Islamic banner. The Dutch colonial government was quite aware of the issue's sensitivity. It forbade newspapers and Islamic leaders from even mentioning the story of Omar al-Mukhtar with the result that the proposed boycotts against Italy could not become widespread. The effectivity of Dutch policy snuffed out the possibility of the figure of Omar al-Mukhtar becoming a rallying point for those politically active in the struggle against colonialism. Those that would become Indonesian National Heroes with Islamic roots were in fact figures re-cast in a national, secular mould. After Indonesian independence it was national, local identity which dominated over that of Islamic martyrdom.
\end{abstract}

Kisah perjuangan Omar al-Mukhtar dalam melawan kolonialisasi Italia menjadi kisah yang menginspirasi gerakan anti-kolonialisme di HindiaBelanda yang dimotori oleh kalangan politisi muslim melalui semboyan Pan-Islamisme. Pemerintah kolonial Belanda merespon dengan hati-hati isu sensitif ini dengan melarang koran dan pemimpin Muslim menceritakan kisah perjuangan Omar al-Mukhtar. Namun, pelarangan ini tidak cukup berhasil. Omar al-Mukhtar menjadi inspirator gerakan anti-kolonialisme. Mereka yang disebut sebagai pablawan nasional dengan latar belakang muslim sebenarnya tokoh-tokoh yang dihadirkan dengan nuansa nasional/sekuler. 
Setelah Indonesia merdeka, identitas lokal-nasional itulah yang kemudian lebih dominan ketimbang identitas keislaman.]

Keywords: Islamic martyr, national heroes, Omar al-Mukhtar

\section{A. Introduction}

Far too easily overlooked and not prominent on the international political stage it is Indonesia, a land both geographically and culturally distant from the Middle East, which warrants considerable attention of Islam-related political scholars of the twenty-first century. Today it is the country where most Muslims in the world live and the role of Islam in its society has recently been growing both culturally and politically as large sections of Indonesian society are taking to Islam as marker of their personal identity. Never having been the heartland of Islamic teaching, Indonesia's location, local customs and diversified culture has mixed with Islamic teaching over the centuries to form, perhaps more outspoken here than in other regions, its own flavor of Islam.

While martyrdom is commonly accepted in Islamic ideology, ${ }^{1}$ in Indonesian political thinking it has not grown into a motivating force for the masses. In the early twentieth century the indigenous Islamic scholar Omar al-Mukhtar fought against Italian colonisation of Libya for many years before eventually being capture and killed. Both Muammar al-Gaddafi as well as the group who overthrew him in 2011 had and have adopted Omar al-Mukhtar as a hero. However, the figure of Omar alMukhtar as "Islamic Martyr" is largely unheard of in Indonesian society. Under the prevalent Pan-Islamist anti-colonialism of the 1930s and with Indonesia being such a vast land filled with people sharing a common Islamic identity and having suffered under a yoke of colonisation, the development of a political ideology of the Islamic Martyr fighting colonialism latching on to the case of Omar al-Mukhtar in Libya is intriguing through its absence. This essay will focus on local responses in the Dutch Indies to the historical figure of Omar al-Mukhtar in order to explain why this figure as Islamic martyr opposing colonialism did not emerge as anti-colonial rallying point of Pan-Islamism. By framing

${ }^{1}$ For a comprehensive consideration of the concept see: David Cook, Martyrdom in Islam (Cambridge: Cambridge University Press, 2007). 
the concept within a larger political and historical context the essay will also show how anti-colonial ethnic nationalism became historically more dominant than Pan-Islamism as identity marker and political force.

Islam has always had a considerable impact on Indonesian society ever since it reached the shores of these islands. Islam arrived by trading ship through the ages and having found gradually more followers in these islands since the 13th century, is has become the religion which links together the largest group of the people living in the islands of Indonesia. This power of Islam to harness populous masses and function as a focal point of identity is always inherent to the religion itself. The Dutch colonizers of Indonesia who ruled the whole archipelago realized the immense rallying power of Pan-Islamism. Especially the potential political power of Islam was watched very closely by the Dutch colonial administration. According to Snouck Hurgronje, their foremost expert in the field of Islamic studies, Pan-Islamism did not constitute an organized political force but relied upon a concept of world domination by Islam which was so unrealistic that it only appealed to uneducated Muslims and could be no more than a local political nuisance. ${ }^{2}$ A local political nuisance was however something the indigenous Indonesians could have latched on to stir up the fires of rebellion against the Dutch. Snouck Hurgronje foresaw the possibility of Pan-Islamism spreading amongst the millions of small peasants in the Indies, although he was optimistic that the Dutch government could act to avoid this potential problem. ${ }^{3}$ This was the situation in the early years of the twentieth century. However the political world was to change in the later decades. Recognizing the huge potential of the large Islamic population, indigenous politicians proved very apt at continuously trying to build a power base centering on Islamic values.

As Snouck Hurgronje correctly saw, Islamic identity in the 19th and 20th century was always there, but the political power it could constitute was only gradually being explored. Rebellions were rife during the colonial era. In the agrarian society of Indonesia the rebellions of these peasants have been well documented. ${ }^{4}$ The uneducated 'natives' were to a large

${ }^{2}$ C. Snouck Hurgronje, Nederland en de Islam (Leiden: E.J.Brill, 1915), pp.112-113.

${ }^{3}$ Ibid., p. 99.

${ }^{4}$ See: Sartono Kartodirdjo, The Peasants' Revolt of Banten in 1888: its Conditions, Course and Sequel: a Case Study of Social Movements in Indonesia ('s-Gravenhage: Martinus 
extent Islamic and there were huge numbers of them. ${ }^{5}$ These numbers would become the principal weapon for any struggle against the Dutch colonial masters. Fighting mostly against social unrest caused by economic pressures perceived to be unfair, the indigenous masses rallied around Islamic-traditional power concepts to fight the colonizer. ${ }^{6}$ Indigenous elites understood this and incorporated an element of Islamic-traditional power in their struggle for political power. One need only to look to Diponegoro to see this exemplified as Diponegoro was depicted as not only a Javanese Prince but also a devout Muslim. Taking great care to portray themselves as local leaders vested with religious authority, the anticolonial forces thus combined both the concept of Islam and traditional cultural 'tribal' rights and elements of indigenousness. Through this they had the authority to challenge the colonial rule of the Dutch and they could become the focal point around which the masses gravitated. These elites have been remembered, the masses they led have not.

\section{B. Images of Indonesian Heroes}

It is however for their anti-colonial struggles and elements of 'tribal', regional power, not specifically for their Islamic martyrdom that these members of the local indigenous elite have been immortalized by the nation-state of Indonesia as heroes. Those earliest heroes of Indonesia are easy to find. There is an official list of them and the list is very diverse by design. The list actually continually grows as people are being recognized for their service to Indonesia and are bestowed the title of 'National Hero.' Politically it remains a sensitive issue today. Only certain individuals have received the title of 'National Hero of Indonesia' and school children must learn about their glorious deeds. ${ }^{7}$ Next to the wife of the deceased former president Suharto, we also find more widely respected historical figures such as the seventeenth century heroes of the Sultans of Banten, Aceh, and Mataram. All are on the

Nijhoff, 1966).

${ }^{5}$ In 1915 Snouck Hurgronje estimated 35 million. See: C. Snouck Hurgronje, Nederland en de Islam (Leiden: E.J. Brill, 1915), p. 96. Today there are about 180 million.

${ }^{6}$ Sartono Kartodirdjo, The Peasants' Revolt of Banten in 1888, p. 316.

${ }^{7}$ For one such approved lists for children by the director general of lower and secondary education. See: Team Penyusun Bahtera Jaya, Album 90 Pablawan Nasional dan sejarah perjuangannya (Jakarta: Bahtera Jaya, 1989). 
list based on their historical roles fighting foreign invaders. Perhaps the most illustrious example is Prince Diponegoro who fought the Dutch in the Java War (1825-1830) and was later exiled to Makassar. A believer in Javanese mysticism, he saw himself ordained to lead a Holy War and was seen as the Javanese Messiah sent to deliver the people from colonial rule. He typifies this distinct syncretism that permeated Indonesian society so strongly. It is important to stress that Diponegoro was seen by the general population as straddling both the Islamic concept of the Mahdi and as the Javanese Ratu Adil concept. ${ }^{8}$ Diponegoro's character appears seemingly effortlessly to combine Javanese mysticism, which has no place in orthodox Islam, with Islamic elements of fighting a Holy War as a Javanese Messiah.

Indonesia is a nation encompassing an extremely large geographical area rich in ethnic diversity. Moreover, the suffering and resistance against colonial oppression was not monopolized by Islamic members of society. In searching for a concept of Islamic martyrs, the devoutly Islamic Acehnese would qualify as no other location and people. Their resistance against the Dutch is highly respected in Indonesia and their struggle cost many lives. It was only in the beginning of the twentieth century that the Dutch colonial armies managed to break most of the Acehnese resistance. The Islamic element in Acehnese identity and resistance is widely recognized. After the initial invasion of Aceh by the Dutch in 1873, the Acehnese lost the battles but undertook guerrilla warfare. By 1881 Acehnese resistance had turned more Islamic as it was being lead by Islamic teachers. ${ }^{9}$ These leaders attacked the Dutch colonial forces and for years managed to avoid capture. They have become heroes who fit in the national identity portrayed by the Indonesian state. A book dedicated to the memory of the Acehnese heroes has a list of those who fought the Portuguese 'aggressor' and a longer one of those who fought the Dutch 'aggressors.' Naturally no heroes are to be found among those who resisted later post-war military actions. ${ }^{10}$ One can instantly

${ }^{8}$ Howard M. Federspiel, Muslim Intellectuals and National Development in Indonesia (New York: Nova Science Publishers, 1992), p. 131.

${ }^{9}$ M.C. Ricklefs, A History of Modern Indonesia since 6.1200 (Houndmills, Bastingstoke, Hampshire: Palgrave, 2001), p. 187.

${ }^{10}$ For a list see: Panitia Besar, Kenang-kenangan kepada para Pablawan Atjeh (Sumatra Utara: Panitia Besar peringatan tiga pahlawan nasional tgk. Tjhik Ditiro, Tjut Njak 
see that the concept of 'National Heroes' has weaknesses and draws but loosely on Islam for the identity of these heroes. Great care is taken to include other heroes in the list of National Heroes. This reflects of course the complexity and heterogenic nature of Indonesia as a land of many people and customs, making it extremely difficult historically to recruit one hero who could appeal to all Indonesians as the ideological framework was produced by the nationalist politicians who demanded inclusion of people from outside the umma. The conclusion here is that the 'Heroes of Indonesia' are those who conform to an inclusive ideal allowing a multitude of groups and people to feel part of the nationstate of Indonesia. Those who rebelled against the Indonesian state after World War II and also tried to use the political potential of Islam as mass-motivator were summarily excluded from national memory.

Looking at the martyr as a historical hero would, however, be doing an injustice to the bottom-up dynamic so typical of the resistance against the colonial power. The ulama during the Aceh war had tried to motivate ordinary people to fight a Holy War against the oppressors. According to Ibrahim Alfian, this was the cause of the courage and willingness of the Acehnese to endure suffering. ${ }^{11}$ There one can find the ordinary martyr. Intuitively being felt as a cause worth fighting for, Islam was seen as a source of strength by the ordinary people in their struggle against hardships and oppression. While the ideology of an Islamic martyr was not pronounced, it was there as a motivating force. For every well known symbol such as Omar al-Mukhtar or Diponegoro there are the thousands of ordinary followers who follow these same principles to a certain extent. The masses also had this Islamic unifying identity which could provide an ideology for resistance. Historically it has been documented that the ordinary Indonesian peasants turned to Islam for strength. Islam gave them a belief to fight a Holy War, as well as invulnerability to the bullets of the hated Dutch and their servants. ${ }^{12}$ The 'magic' of Islam was based upon the syncretism of traditional beliefs and elements of Islam as sacral power. Many died believing in the power of Islamic scholars or haji performing rituals to protect them Dhien dan T. Umar, 1964), pp. 41-43.

${ }^{11}$ Ibrahim Alfian, Perang di Jalan Allah: Perang Aceh 1873-1912 (Jakarta: Pustaka sinar harapan, 1987), p. 151.

${ }^{12}$ Sartono Kartodirdjo, The Peasants' Revolt of Banten in 1888, pp. 236, 238-239. 
from enemy bullets. ${ }^{13}$ The extent to which this ideology and political concept permeated through the lower levels of society remains an area open to many questions. What is certain is that there was an element of belief in Islam and a willingness to suffer while believing in the power of Islam. Dying for Islam as such was never the goal though. Elites as well as ordinary people sought only to mobilize the power Islam could give them to reach their goals. In the modern society of the twentieth century, it were the young anti-colonial political intellectuals who brought Islam's potential as politically potent power into the Indonesian political arena in order to oppose Dutch domination.

\section{Islamic Political Climate and Socio-Ideological Movements}

Politically for Islam in the Indies 1911-1912 are important years. It is in those years that some form of Islamic togetherness crystallized in the islands of what would become Indonesia. Sarekat Islam was founded then, as well as Muhammadiyah. The Sarekat Islam was originally founded as a result of an economic split in 1911 by Javanese members from an association for mutual help controlled by Chinese merchants on Java. Originally there was a strong trader background to the membership of the Sarekat Islam. ${ }^{14}$ The Muhammadiyah movement coincided historically with the Sarekat Islam which was active politically and tried to group all Muslims and excluded non-indigenous people. These movements resulted in the absorbing of Islam in Indonesian political life. This political evolution was eventually countered however by a more traditional element of followers of Indies Islam, which would crystallize in 1926 in Nahdlatul Ulama. The Nahdlatul Ulama movement was in that sense a reaction of conservative Islamic elements towards the rising tide of modernist-reformist Islam. ${ }^{15}$

While inside the Dutch East Indies there was a spiritual revivalism of Islam occurring vis-à-vis the traditionalists as well as a political power concentration vis-à-vis the nationalist movement and the communist

${ }^{13}$ Ibid., p. 232.

${ }^{14}$ See the appendix published in A.P.E. Korver, Sarekat Islam 1912-1916 (Amsterdam: Historisch Seminarium van de Universiteit van Amsterdam, nr3 serie Amsterdamse Historische Reeks, 1982), p. 209.

${ }^{15}$ Deliar Noer, The Modernist Muslim Movement in Indonesia: 1900-1942 (Oxford, Kuala Lumpur: Oxford University Press, 1978), pp. 222-223. 
movement, one must not forget those outside intellectual influences which played a major part in these developments. Internationally the year 1924 stands out since in that year the Islamic Caliphate was brought to an end and the power of the umma had succumbed to regional pressures. Despites attempts to restore the Caliphate it was never to be. Subjects of the Dutch East Indies followed closely at the attempts by an increasingly politically divided Muslim world to recreate the Caliphate. They even held several local Islamic congresses to discuss the matter. In the Islamic congress at Bandung in 1926 it was formally decided to send Tjokroaminoto, the respected leader of Sarekat Islam, and KH. Mas Mansoer of Muhammadiyah as delegates to the Islamic congress in Mecca of $1926 .{ }^{16}$ Politically Islamic politicians were connected to the international Islamic network.

Interestingly, the extent to which the Middle East influenced student elites ideologically to reform Islam is under debate. According to Nakamura, the influence of Egyptian Islamic reformism on Muhammadiyah only began in the 1920s with the generation of students like Abdul Kahar and even then the main component of the movement was a "development from within." 17 This would mean that the influence of the international world in this process is not to be overstated. Indies students in the Middle East came in contact with the geo-political problems occurring in the Middle East in the early decades of the 20th century. When they returned they could join groups like Persatuan Islam, who discussed the magazines like al-Manar (the Beacon) printed in Cairo and al-Munir (the Light) from Singapore. ${ }^{18}$ Despite the degree to which the Islamic political movement had grown by itself, there was clearly an international ideological input as primarily Javanese and Sumatran Muslims saw themselves part of the Islamic world. Their sons studying in the Middle East became exposed to the political movements there during the 1920s and 1930s. In this context the historical case of the

${ }^{16}$ Ibid., p. 222-223.

${ }^{17}$ Mitsuo Nakamura, "Professor Haji Kahar Muzakkir and the development of the Muslim reformist movement in Indonesia," in Benedict R. O'G Anderson, Mitsuo Nakamura and Mohammad Slamet (eds), Religion and social Ethos in Indonesia (Clayton: Monash University, 1977), pp. 7-8.

${ }^{18}$ Howard M. Federspiel, Persatuan Islam, Islamic reform in Twentieth Century Indonesia (Ithaca: Modern Indonesia Project Cornell University, 1970), p. 12. 
rebellion of Omar al-Mukhtar against Italy and his death in 1931 which angered the international Muslim world came at just the right moment to have an impact also in Indonesia. Omar al-Mukhtar had fought the Italian colonialists for twenty years from 1911 until 1931 when he was executed on 16 September 1931.

\section{Italian Connection}

Tjokroaminoto, who by now had become the most widely respected Islamic leader of the time, took the initiative for a Sarekat Islam Party conference to be held on 27-28 June 1931, at Surabaya in order to form a central Al-Islamic Committee. Officially the central Al-Islam Committee had as its goal to fight against attacks on Islam. ${ }^{19}$ In April 1931 derogatory comments on Muhammad the Prophet had appeared on two occasions in the Chinese-Indonesian and Dutch-Indonesian press and these had angered Muslims. As a result of this, protests had broken out, which eventually led to the creation of a centralized al-Islamic Committee by Islamic politicians. Clearly within the political spectrum of what would become Indonesia political Islam was becoming a major player.

The Al-Islam conference, in which 48 Islamic groups and 1.500 people participated, was closely watched by Dutch authorities. Three kinds of attacks on Islam were distinguished in this congress: 1) attacks against Islamic practices such as polygamy by women movements and the nationalist parties, 2) Christian missionary activities, and finally 3) international events such as the Palestine issue, the situation of the Berbers in Morocco and the Italian occupation of Tripoli. While Dutch authorities recognized this final element as a Pan-Islamic aspect of the movement, they also emphasized how a derogatory article in the Indies Chinese press triggered the setting up of this committee to defend Islam. ${ }^{20}$

The attacks on Islam mentioned above, however, already showed a dilemma which was inherent in the Islamic political strategy. Antagonizing women movements and the rival nationalist one fractionalized a political movement which essentially needed to unify activists against the foreign colonial power in order to maximize the chances of being successful

${ }^{19}$ National Archives, Den Haag, Ministerie van Koloniën: Geheime Mailrapporten, series AA, 1914-1952, access number 2.10.36.06. Mailrapport 716x/1931.

${ }^{20}$ Ibid., Mailrapport 716x/1931. 
in mobilizing overall support within the Indonesian Indies population. Targeting Christian missionaries was also problematic because by then they had already established themselves in large sections of the archipelago and had sown the seeds of division among the indigenous people now partly Muslims and partly Christians on the outer islands.

Psychologically connecting Muslims in the Indies to the fate of fellow Muslims in other lands was an attempt to connect politically Islam to the Pan-Islamic movement. The events in Italy were extensively cited. In Batavia at a meeting held by the local Al-Islam committee on 26 July and 23 August 1931 it was reported by the Dutch authorities that many Arabs attended. In the meeting of 26 July the acts of the Italians are specifically mentioned. One speaker exaggeratedly claimed that around a dozen Muslims were thrown out of airplanes from and caught on bayonets by the Italians while being taunted to call upon Allah, that violence was used against thousands because they refused to convert, that women were raped, and that children were sent to Italy to convert. The Dutch report mentioned the emotional responses of the crowd as result of this speech. Another speaker related how 80.000 people were chased from Jebel Akhdar and how Cufra was bombed. ${ }^{21}$ The news of suffering from fellow Muslims stirred up emotions in the Indies. It became a weapon for the Islamic political movement to create political power based upon a genuine concern of Muslims from the plight of their fellow believers.

Another weapon that the Indies Islamic political movement had against the Dutch colonial authorities was the boycott. The actions of the Italian government in Libya sparked the boycott. This move for a boycott materialized much earlier than the death of Omar al-Mukhtar. At a Batavian meeting held by the local Al-Islam committee on 26 July 1931 another speaker called for an Islamic boycott against Italian products. ${ }^{22}$ In that meeting it was noted that Italian products were boycotted in many countries and in the Dutch Indies the best Italian products to boycott were Fiat cars and Pirelli car tires. In the meeting of 23 August, the intelligence report specifically mentioned how the chairman of the Central Al-Islam committee based in Surabaya again claimed that a

\footnotetext{
${ }^{21}$ Ibid., Mailrapport 1035x/1931.

${ }^{22}$ Ibid.
} 
boycott was necessary and that they would notify sister-organizations in Egypt and British-India plus that the Muslims in the Indies would also boycott Italian goods. ${ }^{23}$ These actions clearly do show a Pan-Islamist sentiment of Muslim solidarity.

The Italian consul was aware of this threat and took up correspondence on this matter with the Dutch authorities on 21 September $1931 .{ }^{24}$ On a letter of 1 October the consul declared:

I note with great satisfaction that the Government will take steps to immediately subdue this illegal action and that instructions have been given already to the Police for the prevention of all forms of propaganda in favor of the boycott of Italian goods, as well as to the Heads of the Provinces for the official denying of all lies on alleged Italian cruelties towards Moslems in Tripolis.

Although the Dutch did not forbid the boycott as it fell outside criminal law, they denied the Islamic political movement the possibility to use or refer to the events in Libya in order to avoid a rally around the Libyan Muslim brothers fighting the Italian occupier which could have stirred up feelings in the Indies. By doing so, a narrative of potentially immense political power to rally Muslims based on the story of the Islamic martyr Omar al-Mukhtar was not to be spread in the Dutch Indies.

The Central Al-Islam Committee had planned a meeting in all the areas where it had branches on 11 October 1931 where it would discuss offensive statements against Mohammad in the press and the events in Libya. ${ }^{25}$ Reporting on the meeting of the Batavia branch of the Al-Islam Committee, E. Gobée, the Dutch advisor for domestic affairs, specifically mentioned how an Indies speaker turning to the topic of the Muslims of Tripoli during the meeting, was interrupted by the police and forbidden to do so as this would insult the Italian government. ${ }^{26}$ In later reports it is described how the prohibition to even mention the international abuses against Muslims, based on a government order of 30 September 1931, was seen by the local Indies political activists as an insult to Muslims. ${ }^{27}$

After the Dutch authorities decided to forbid any mention of the
${ }^{23}$ Ibid.
${ }^{24}$ Ibid., Mailrapport 1288x/1931.
${ }^{25}$ Ibid. Mailrapport 963x/1931.
${ }^{26}$ Ibid., Mailrapport 472x/1932.
${ }^{27}$ Ibid., Mailrapport 1025x/1931. 
events in Italy there was no longer any possibility to spread the word. The news of Omar al-Mukhtar had only become clear after the prohibition and thus the story never was told openly. These reports trickled into the Indonesian-language media, but were very tightly watched by the Dutch authorities. A Dutch report specifically mentioned on 21 October 1931 that the news of Omar al-Mukhtar's execution had not become widely known in the Dutch Indies. ${ }^{28}$

The diversity of the Indies of the time and the sheer geographical size combined with the limited financial means of the Indigenous press and low readership of these magazines explains the limited success of the boycott. The activities quickly subsided and never became more than just a political statement of politically active Muslims. The ones that kept watching these events were, however, the Italian Consul of the Dutch Indies and the Dutch authorities. The Italians had an interest in the case of Libyan resistance against the Italians. When some minor Indies newspapers again called for a boycott against the Italian products in November 1931, the Italian consul L. Gensi immediately protested to the Dutch authorities. ${ }^{29}$ When the story of Omar al-Mukhtar was published in a small newspaper in the Indonesian-language press, the Italian consul again reported this to the Dutch authorities. The matter of Omar al-Mukhtar was only indirectly mentioned as in this source where on 11 November 1931 it was alluded to through mentioning the printing of an article from a newspaper in Beirut which mentioned that people in Syria were angry at the death of Omar al-Mukhtar and that this has led to a boycott against Italian products. ${ }^{30}$ The Attorney General R. Verheyen in December 1931 reported to the Governor General of the Indies that the interest in this case had diminished and that a boycott or appeal to boycott was not illegal law and that it was best to undertake no action that might have counterproductive effects. ${ }^{31}$ In 1932 the boycott matter had died down as the press no longer reported any mention of it. What is clear is that the attempts of the Islamic intellectuals trying to guide or steer the public awareness and emotions of the Islamic population were thus greatly hindered by the Dutch efforts and that they seemed to have

\footnotetext{
${ }^{28}$ Ibid., Mailrapport 27x/1932.

${ }^{29}$ Ibid., Mailrapport 1288x/1931.

${ }^{30}$ Ibid.

${ }^{31}$ Ibid.
} 
largely succeeded in silencing the issue. Omar al-Mukhtar as martyr of the Islamic cause seems not to have been prominent in the historical reports of the time because of the prohibition to mention Libya at all.

Yet Omar al-Mukhtar is part of the historical record. We find an answer of the potential sensitivity of this issue in a debate by the Dutch authorities themselves on whether or not the figure of Omar al-Mukhtar was used as a symbol of the Islamic Martyr. Gobée in his report of 11 October 1931 does not mention the name Omar al-Mukhtar directly but notes the unfortunate coincidence of this news of the killing of an 80year old rebel leader from the Sanusi movement in Tripoli when political tension was so high in the Dutch Indies. Gobée also stated that a prayer was held for the dead Omar al-Mukhtar after the Al-Islam meeting but that this was disguised as being for "the dead person of Bandung." ${ }^{2} \mathrm{On}$ 16 October 1931 Gobée wrote that most people on the meeting of the Al-Islam committee of Batavia did not fully understand that reference of going to pray for the victims of Tripoli as a result of the prohibition to talk about Tripoli. It was mentioned specifically in his report that when Dutch authorities asked the indigenous speaker who he was talking about, he stated that he was talking about the victims in Tripoli, not a specific person. ${ }^{33}$ This could be true but on the other hand it seems pretty naive to assume that political activists would give a truthful answer to the Dutch political authorities, especially as it would have lead to problems for them.

Verheyen, the Attorney General of the Netherlands East Indies, stated that he thought that the recently outlawed Indonesian National Party (PNI) was intended by this call for prayers and that Gobée's explanation was simply wrong. He also mentioned that these protests were agitation which would not resonate nor be supported by the general population. ${ }^{34}$ It is also included in a secret report by the Dutch authorities that in a magazine published before the meeting of the Batavia Al-Islam committee on 11 October 1931 there had been an appeal to pray for the victims of the cruelties of the Italians in Libya. In the discussion that had ensued - on the matter whether an appeal to pray for the dead from Bandung was intended to mean Omar al-Mukhtar or the Indonesian

${ }^{32}$ Ibid., Mailrapport 1025x/1931.
${ }_{33}$ Ibid., Mailrapport 1066x/1931.
${ }^{34}$ Ibid., Mailrapport 1095x/1931. 
National Party which had just been banned - the vice-president of the Council of the Dutch Indies seemed to oppose Verheyen's explanation and stated that it would be heresy for devout Muslims to use the mosque to pray for such a political event as the banning of the National Party. ${ }^{35}$ Here ends the official Dutch discussion of the case of Omar al-Mukhtar and the colonial struggle in Libya.

What is interesting is that this seems to indicate that Omar alMukhtar was indeed seen by some as an Islamic Martyr and had as symbol reached as far as anti-colonial Islamic leaders in the Indies who were indeed trying to rally people around Omar al-Mukhtar. In how far Omar al-Mukhtar had the potential to become an Islamic martyr in Indonesia is a counter-factual question that the historical record cannot shed light on. Because of the prohibition to speak by the Dutch colonial authorities the issue was so obscure that the general public could not take full notice nor express support or respond to this concept. The latent danger itself was clearly recognized as well as the fact that Islamic political activists were aware of Omar al-Mukhtar and wanted to use his case for political purposes. Even simply mentioning Libya and thus Omar al-Mukhtar in a political meeting was illegal since 30 September 1931. Any political printed matter talking about Libya was suspect. Thus political Muslims would have taken great care not to leave any proof in order to avoid arrest. We cannot discard the hypothesis that Omar al-Mukhtar was an important symbol in the Dutch Indies at the time. We can only assume that the fact that Dutch colonial civil servants debated the issue indicates that there was an attempt by the Muslim politicians to mobilize the Islamic masses based on the plight of their brothers in Libya.

The fact that politicians in the Indies had started political action based upon the suffering in Libya much sooner than the death of Omar al-Mukhtar in September 1931 does however indicate that he as a person was not an inspirational symbol before his death since no reports or mentions are to be found of him as symbol of struggle from before the prohibition to mention Libya. The suffering of Libyans in general is what brought about protests and leads eventually to a boycott of Italy in the Dutch Indies. The boycott itself seems to be more a threat than a serious action because of Dutch scrutiny. Dutch authorities discussed

${ }^{35}$ Ibid., Mailrapport 27x/1932. 
in secret reports that the events in Tripolitania had an influence on the Muslims in the Indies, but could not totally gauge in how far these events were due to propaganda or genuine concerns of fellow-Muslims. ${ }^{36}$ The pattern is clear. The Dutch were trying to forbid agitation whereas the Islamic groups were trying to bring these concerns to the foreground. The weapons of the local politicians were to bring out anger and mobilize the masses, weaken economic power through boycott, and publicize and protest measures against their freedom of speech both nationally and internationally.

After the Dutch had taken action against the publication of the event and were watching closely, indigenous political activists tried to connect again to their fellow Islamic believers in the Middle East. An article published on 16 October 1931 in Surabaya added to the report. A Muslim writer complained that the Dutch colonial government had forbidden Muslims to speak about the cruelties of the Italians in the Maghreb on fellow Muslims, as well as against the writings in Dutch and Chinese newspapers criticizing Islam. Even the protesting against these events, which was the only thing that the politically weak Muslims could do, was forbidden by the Dutch colonial government. The writer proposed in the article to present these facts before the Palestinian congress of 2 December 1931. ${ }^{37}$ The Palestinian Jerusalem Congress provided them with an opportunity to further this political cause.

Again the Dutch were well informed. The events of the Palestinian Congress were also watched closely. The Dutch investigators reported that the issue of Tripoli was far from forgotten, being mentioned by Abdurahaham Azzam from Egypt. The Dutch authorities quoted a report from a Palestine magazine on 27 February 1932 which related how the remaining Muslim forces had fought on after the death of Omar al-Mukhtar against the Italian oppressors. ${ }^{38}$ Clearly vigilant, Dutch authorities discussed the Egyptian press, which brought news of the Islamic congress of Palestine. ${ }^{39}$ Abdul Kahar Muzakir was the Indies representative at this congress and the Dutch authorities report an article by him in a magazine of 11 December 1931 which they claim shows

\footnotetext{
${ }^{36}$ Ibid.

${ }^{37}$ Ibid.

${ }^{38}$ Ibid., Mailrapport 358x/1932.

39 Ibid., Mailrapport 35x/1932.
} 
his views. In this article Abdul Kahar Muzakir specifically complained about the demise of the Caliphate, abuses of Muslims in Morocco, enemies of Muslims being in Palestine but lack of solidarity and will to politically unite between Muslims. ${ }^{40}$ From this letter the Dutch concluded that he would not become a major political threat. The Dutch also had obtained a copy of the resolutions of the Islamic congress in Jerusalem, but concluded that these would not have much effect. The Islamic congress protested against Muslim oppression in Libya in point III of the resolutions and also against the Dutch government in point VI in protest against all imperialism. ${ }^{41}$ Dutch conclusions about the resolutions of the Islamic congress turned out to be right.

In an intelligence report of 3 April 1932 the Dutch authorities mentioned that their prohibition to mention Libya had succeeded in reducing the visibility of criticisms. The policy was best left unchanged for the meeting in Malang by the Al-Islam Islamic congress in Indonesia. ${ }^{42}$ It is at this congress that the indigenous politicians wanted to bring up the results of the International Islamic Congress in Palestine. Tjokroaminoto, who had been instrumental in the creation of the central Al-Islam Committee, was losing influence. On the Islamic congress in Malang, held on 15-18 April 1932, the Dutch authorities reported that the leadership of the Sarekat Islam Party and Tjokroaminoto met with little enthusiasm from the audience. The report explicitly stated that the influence of Tjokroaminoto was waning and a discussion on the International Islamic Congress in Palestine, which was said to be held, turned out not to have taken place at all. ${ }^{43}$

That meant the end of the Italian issue for Dutch Indies politics. Dutch efforts had born fruit and the matter of Libya disappeared from the press. Omar al-Mukhtar had not become a publicly known name for the general public by 1932. The momentum for Pan-Islamism and the possibility to create a Pan-Islamic Islamic martyr as political symbol had faded in the Indies. Omar al-Mukhtar as historical figure was no longer in the forefront of the local political debate. The hope to defeat the Dutch colonial power now was to have a 'Pan-Indonesianism' where

${ }^{40}$ Ibid., Mailrapport 63x/1932.
${ }^{41}$ Ibid., Mailrapport 735x/1932.
${ }^{42}$ Ibid., Mailrapport 358x/1932.
${ }^{43}$ Ibid., Mailrapport 472x/1932. 
all the people of the archipelago grouped their anti-colonial energies no matter what religion or ethnic background.

On 14 December 1934 Tjokroaminoto died and with him the father of Pan-Islamism in the Indies was removed from a political spectrum increasingly dominated by nationalists. He would however be recognized as National Hero in 1961. Pan-Islamism proved elusive as concept for the future Indonesia just as it had been internationally, but would occasionally resurface. The story of Omar al-Mukhtar had great potential for indigenous politicians seeking to rally the Muslim population, but the swift reaction of the Dutch had prevented the spark to take hold of the indigenous population in sufficient numbers. It is important however to realize that there was a general feeling of unhappiness that the Muslims were insulted and the Islamic leaders were trying to tap into this politically by using not only international Pan-Islamic feelings based on Libya and other countries but also mostly domestic issues as insulting Islam and Muhammad the Prophet. In fact it was a local Indies newspaper magazine's comments that caused the Al-Islamic committee and Muslim togetherness to become politically active. Islamic political leaders were able to play upon that theme of insulting Muslims until the prohibition to speak about Libya. Only after that event, did the story of Omar al-Mukhtar reach the Indies. It was however too hard to notice for ordinary Muslims because of the prohibition to speak about these matters in the Indies.

\section{E. Historical Aftermath}

The story of the historical figure Omar al-Mukhtar ends there. During the Second World War the Japanese had established a military control which was even stricter than that of the Dutch and Italy was allied with Germany and Japan which automatically disqualified any consideration of use of the memory of Omar al-Mukhtar for any anti-Western colonial propaganda purposes. On the contrary, the indigenous Diponegoro was used as symbol of indigenous resistance against the Dutch during the Japanese era. In the Post-Japanese era of the independent nation-state of Indonesia it can be said that it was K.H. Zainal Mustafa who came to embody the dual concept of recognized national hero as well as Islamic martyr. He was officially recognized as 
a national hero in 1972. In Libya as well, Omar al-Mukhtar was recast in that same mould as national hero as well as an Islamic martyr. An American film produced in $1981^{44}$ brought Indonesia, as well as the rest of the world, back into contact with the historical figure and memory of the Islamic martyr Omar al-Mukhtar but his appeal in Indonesia has remained limited.

It is only fairly recently in the later years of the Suharto era and beyond that the element of Islam has managed to obtain a larger role in the public and political expression of people's identity. It was also fed by that same sympathy for fellow Muslims internationally as during the days of Omar al-Mukhtar in the 1930s. We see a similar evolution of attempts to mobilize members of Indonesia's Islamic population as muscle of political strength and Pan-Islamism remains a quicksilver force in Indonesian Islamic society basically because the umma itself sees all Muslims as brothers and thus resonates with this concept. The Islamic martyr is, however, marginalized in the Indonesian mainstream population. The anti-colonial context in which it was most easily harnessed has disappeared to a large extent internationally and domestically the Islamic dominance in Indonesian identity is obvious to all and no longer needs martyrdom.

\section{F. Conclusion}

The historical figure of Omar al-Mukhtar and attempts at casting him as an Islamic martyr by political Islamic activists internationally in the 1930s, had a potential to resonate in the Indies only because of the umma and Pan-Islamism as anti-colonial force. The story of Omar alMukhtar and his capture and death by the Italians constituted a potential to mobilize the Islamic segment of indigenous Indies society in the political climate of rising anti-colonialism of the 1930s. The efficient colonial control, however, made certain that this potential never was realized and succeeded into fairly quickly and efficiently preventing a potential threat to the colonial state. The concept of Libyan suffering however was the trigger for sympathy and not the potential destructive

44 'The Lion of the Desert', ironically as history keeps repeating itself, the story of Omar al Mukhtar was again prohibited to be told in Italy as the movie was banned there in 1982. 
force of an Islamic martyr as such. Martyrdom was not the goal of the Indonesians in the 1930s. It was anti-colonialism and a weak point remained, namely that as these colonial interests were defeated by more local, nationalist interests then the umma historically would succumb to these ethnic-regional, national concerns.

In a post-colonial world where Islam is seen as a power or an element of identity in alignment with the nation-state, the Islamic martyr such as Omar al-Mukhtar in his native Libya only resonates as symbol of indigenous local struggle rallied around Islam in the mould of the indigenous nation-state replacing the colonial power. The selection of Indonesian Islamic national heroes clearly echoes that picture and Islam has become a respected stakeholder in today's Indonesia. In a postcolonial world in Indonesia this harnessing of the potential mobilization power of Islam by the nation-state was therefore less appealing because of the dominance and prominence of Islam in Indonesian national identity already being recognized. The risk to the nation-state of destabilization by a too strong Islamic hold on the non-Islamic minorities also worked as an opposing factor in an Indonesian nation-state framework. The Islamic martyr from Indonesia does re-emerge but remains fairly marginalized having an appeal only on certain Muslim individuals for struggles outside of the indigenous homeland just as it did during the 1930s and before. 


\section{BIBLIOGRAPHY}

Alfian, Ibrahim, Perang di Jalan Allah: Perang Aceh 1873-1912, Jakarta: Pustaka sinar harapan, 1987.

Bahtera Jaya [Team Penyusun], Album 90 Pablawan Nasional dan sejarah perjuangannya, Jakarta: Bahtera Jaya, 1989.

Cook, David, Martyrdom in Islam, Cambridge: Cambridge University Press, 2007.

Federspiel, Howard M., Persatuan Islam, Islamic Reform in Twentieth Century Indonesia, Ithaca: Modern Indonesia Project Cornell University, 1970.

----, Muslim Intellectuals and National Development in Indonesia, New York: Nova Science Publishers, 1992.

Hurgronje, Snouck C., Nederland en de Islam, Leiden: E.J.Brill, 1915.

Kartodirdjo, Sartono, The Peasants' Revolt of Banten in 1888: its Conditions, Course and Sequel: a Case Study of Social Movements in Indonesia, 's-Gravenhage: Martinus Nijhoff, 1966.

Korver, A.P.E., Sarekat Islam 1912-1916, Amsterdam: Historisch Seminarium van de Universiteit van Amsterdam, nr3 serie Amsterdamse Historische Reeks, 1982.

Nakamura, Mitsuo, "Professor Haji Kahar Muzakkir and the Development of the Muslim Reformist Movement in Indonesia" in Benedict R. O'G Anderson, Mitsuo Nakamura and Mohammad Slamet (eds), Religion and social Ethos in Indonesia, Clayton: Monash University, 1977.

Noer, Deliar, The Modernist Muslim Movement in Indonesia: 1900-1942, Oxford, Kuala Lumpur: Oxford University Press, 1978.

Panitia Besar, Kenang2an kepada para Pablawan Atjeh, Sumatra Utara: Panitia Besar Peringatan Tiga Pahlawan Nasional tgk. Tjhik Ditiro, Tjut Njak Dhien dan T. Umar, 1964.

Ricklefs, M.C., A History of Modern Indonesia since c.1200, Houndmills, Bastingstoke, Hampshire: Palgrave, 2001.

\section{Archives}

National Archives, Den Haag, Ministerie van Koloniën: Geheime Mailrapporten, series AA, 1914-1952, access number 2.10.36.06. 
Secret Mail Reports: Mailrapport 716x/1931, Mailrapport 963x/1931, Mailrapport 1025x/1931, Mailrapport 1035x/1931, Mailrapport 1066x/1931, Mailrapport 1095x/1931, Mailrapport 1288x/1931, Mailrapport 27x/1932, Mailrapport 35x/1932, Mailrapport 63x/1932, Mailrapport 358x/1932, Mailrapport 472x/1932, Mailrapport 735x/1932. 
Frank Dhont 